\title{
Military Families: Topography of a Field
}

\author{
Sofia K. Ledberg and Chiara Ruffa
}

\section{Contents}

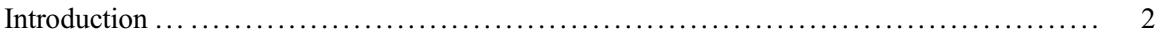

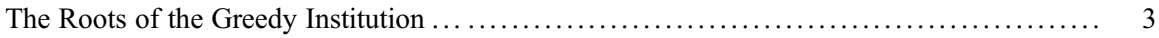

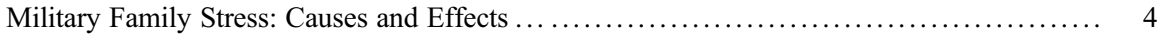

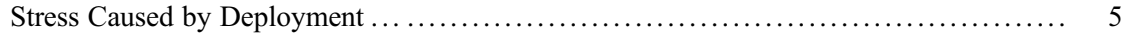

Variations in Stress Before, During, and After Deployment ...................... 5

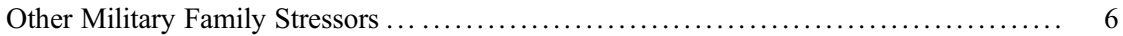

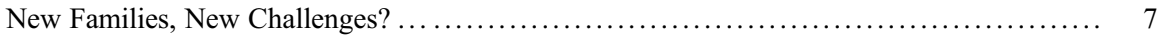

Social Support ......................................................... 9

Concluding Remarks: Continuing to Develop the Debate on Military Families ........... 10

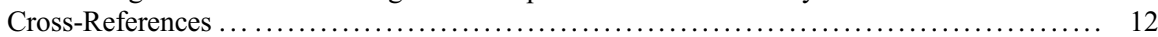

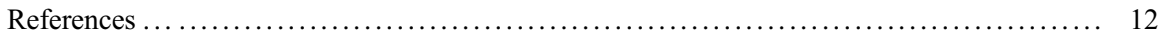

\section{Abstract}

Over the past decades, debates revolving around the role and challenges of military families have developed into an important subfield in military sociology. Throughout history, military families have played an important role for military forces, and in the post-World War II era, the role of the family has shifted as a consequence of military professionalization. Research on military families explores the different demands placed upon service members from both the military organization and the family. More recently, such research has studied how the inclusion of women and gender minorities, operational deployments, and

S. K. Ledberg

Swedish Defence University, Stockholm, Sweden

e-mail: Sofia.Ledberg@fhs.se

C. Ruffa (ه)

Swedish Defence University, Stockholm, Sweden

Uppsala University, Uppsala, Sweden

e-mail: Chiara.ruffa@fhs.se; chiara.ruffa@pcr.uu.se

(C) The Author(s) 2020 
broader societal changes transformed the composition, stakes, and challenges of military families and the traditional idea of the military spouse.

\section{Keywords}

Military spouses $\cdot$ Greedy institutions $\cdot$ Family stressors $\cdot$ Social support

\section{Introduction}

Over the past 30 years, discourse surrounding military families has become a core concern of military sociology. The literature on the military family begins with the assumption that the military profession is a special job because of its special function and its demands on time and other commitments. Further, the military demands that its members strip away some of their previously existing identity to become part of an organization where collective culture matters more than the individual or where collective culture drowned out an individualistic culture (Winslow 1997). Against this backdrop, where does a service member's family fit - is it a support mechanism, a hindrance, or both?

Importantly, these questions began to be considered in the mid-1980s by Mady Segal. She introduced the concept of a "greedy institution," which equated military families to military organizations because both put demands on their "members" and both fit the definition of a "greedy institution" (Segal 1986). Mady Segal's work was groundbreaking: with the transition from a conscript US military to an All-Volunteer Force (AVF), more and more enlisted personnel had families. During conscription, young conscripts generally started families after they returned to the civilian sector. The AVF involved longer tours of duty and a higher likelihood of reenlistment. Families became a new norm (De Angelis et al. 2018).

With frequent deployments abroad and within-country relocations, wives of service members and women service members found themselves overtaxed, and the notion of the greedy institution helped to explain why. They faced demands from two greedy institutions - the family and the military. In the model she developed, Segal identified four components of military membership likely to create friction with family life, namely: "(1) risk of service member injury or death, (2) frequent relocations, (3) periodic separations, and (4) foreign residence" (Segal 1986). This model suggested an unavoidable tension between two greedy institutions. Because her model is context and time specific, its application is limited, particularly with reference to Europe. Nevertheless, the greedy institution model has profoundly influenced the debate within the field and has served a reference point for all the literature on the topic (Heinecken and Wilén 2019; Button and Diallo 2020; Van Slyke and Armstrong 2019). Drawing on Segal's work as well as reflecting on further societal development and contextual specificities, the literature has focused on the stress relating to military organization and family, the role of deployments, psychological effects, changes reflecting broader societal transformations, and support roles. 
This chapter begins with an overview of classical texts focusing on the, at times, incompatible demands placed on service members by the military and the family. It thereafter introduces key issues within the more recent literature, including the various sources of military family stress, including operational deployment, the impact of societal changes on the military family, and the social support role that military families play. The chapter concludes with a number of avenues for future research.

\section{The Roots of the Greedy Institution}

The most widespread idea within the research field of military families is that service members and their families must navigate the demands of two greedy institutions: the armed forces and the family (Segal 1986, 1989; Segal and Jesse 1993; Segal et al. 1992; Moelker et al. 2015, 2019). The underlying idea put forward by Segal is that greedy institutions "compete for the commitment, loyalty, time and energy of their members" (Segal 1986, 9). Her model suggests an unavoidable tension between those two greedy institutions.

The literature on the military family was primarily about the US case initially mostly because there were more stresses on the US force compared to Europe. Under a draft system, the enlisted force was young and had short service obligation and hence was generally not married and did not have children. The introduction of the All-Volunteer Force changed the demographics and tenure of the enlisted force for the USA. The draft ended in 1973, and by the mid-1980s, the effects of eliminating conscription had filtered through the institution. Women also entered the military at much greater rates partly because the military could not recruit enough men. Both had implications for the tension between family and military facing service members.

To make the tension more extreme, in the 1980 s, military families struggled with the USA's continental geography, which often separated nuclear from extended families. The individualist culture and limited social services exaggerated the hardships. There were few safety nets or buffers that could partly temper the greediness of either the military or family. In that new context, the military family certainly was to a large extent integrated in the military community, and there were no real boundaries between the (usually male) officer's military and (usually his) private life. For example, US servicemen generally lived in military installations together with their families (Segal 1986: 23), especially in the "Little Americas" that were created in Germany and other places during the Cold War (Baker 2004). At that point in time, the military also influenced the family of servicemen to a great extent. Stanley and coauthors wrote that "the relationship between the Army and army families will never achieve parity. By the very nature of its responsibilities, the Army must maintain control and occupy the dominant role" (Stanley et al. 1990).

Service members stayed longer in the armed forces and were, consequently, more likely to marry and raise children while serving (Segal and Segal 2006). As a consequence, instead of being pressured by only one greedy institution, i.e., the 
military, the officer now came to face an additional set of demands from the family, which according to Segal share several traits of a greedy institution (1986). Thus in 1986, the problems with military families began to surface, and the greedy institution model was helpful to navigate this new time and context.

Even though the greedy institution model has generally been the lenses to view possible tensions between military and family felt by service members, contemporary scholars note that the greediness of the military institution specifically varies over time and place (Moelker et al. 2015; De Angelis and Segal 2015). Until the mid1990s, the model really was not relevant in Europe because they used a conscription model, the draftee obligation was short, and the international missions were few.

The European literature on the military family emerged mostly after the end of mass conscription and when deployments to Afghanistan became a reality. Within this later literature, scholars discovered the limits of the greedy institution model of the late 1980s. Moelker et al. (2019) argue that the concept of the family as a greedy institution still is valid but argue that it needs elaboration and refinement (Moelker et al. 2019). Along similar lines, for instance, Gribble et al. (2019) illustrate that UK military spouses experience the military institution as exercising control over them and their families, thereby challenging the identity of the nonmilitary spouse. At the same time, it renders support to military spouses and families through the creation of a military community. It remains to be seen how the reintroduction of conscription, with equal obligations for men and women, in countries like Sweden and Norway may influence the model.

\section{Military Family Stress: Causes and Effects}

As discussed above, a frequent starting point of the literature on military families is that service members are facing demands from both the military institution and their families, making them trapped between two greedy institutions. Another topic in focus in research on military families is the stress experienced by the military family and the consequences of this for the well-being of spouses and children as well as for the relationship between them. Reaffirming, and adding to, the factors that Mady Segal identified in the mid-1980s, Dursun and Sudom (2015: 129) summarize the potential stressor of the military family as "frequent relocations, temporary housing, spousal unemployment and underemployment, separations, deployments to hostile situations, and long and unpredictable work hours" (see also Dursun et al. 2019: 105; Meadows et al. 2016). Another study on the British Army, using mixed interview methods in investigating the experiences of British Army wives, came to similar conclusions regarding factors that cause stress (Dandeker et al. 2015). Aside from relocations and separation during deployment, these women also identified the demands of the army, which were seen as nonnegotiable, as causing tensions (ibid.,: 114).

Separation due to operational deployment has gained particular traction in the literature and is perhaps the most important cause of stress for military families. Research on military deployment and the well-being of military families gained 
momentum as the number of foreign military missions increased in many Western states in the 1990s. At the same time, as the militaries downsized, they were generally used more frequently abroad, especially in peacekeeping missions. These new missions proved stressful for both the personnel involved and their families back home, partly because of their new and not strictly military focus (Moelker et al. 2015; Bartone et al. 1998; Segal and Segal 1993).

\section{Stress Caused by Deployment}

The debate around military deployment explores which factors prevailed in terms of length, frequency, exposure, or just the fact of deployment. Whereas the literature tends to agree that operational deployment and separation are major stressors for the military family as well as for the officer or soldier, there are different and contrasting findings regarding the impact of the length of deployment. In Buckman et al.'s review of nine studies on the impact of deployment length, seven studies found that longer deployments had a negative impact on the deployed person's health (Buckman et al. 2011). Interviews and surveys of US peacekeepers deployed to Bosnia reached similar conclusions (Bartone et al. 1998). As for the well-being of the family left behind, a quantitative study including more than 250,000 wives of US soldiers in active duty in Iraq and Afghanistan similarly found correlations between longer deployments and the frequency of mental health diagnoses, such as depression and sleep disorders (Mansfield et al. 2010). Yet results in other studies challenge the correlation between the length of deployment and the stress and well-being of military families (Everson et al. 2017; Dandeker et al. 2015). Also, the level of intensity of engagement is, somewhat unsurprisingly, important. Life-threatening and dangerous missions increased the likelihood of long-term stress and secondary traumatization (Moelker and van der Kloet 2006). This strand of research peaked with large-scale boots-on-the-ground operations in Iraq and Afghanistan (De Angelis et al. 2018).

\section{Variations in Stress Before, During, and After Deployment}

Studies on military families and deployed officers and soldiers have also concluded that the level of stress varies during the cycle of deployment (Tomforde 2015; Bartone et al. 1998; Dursun and Sudom 2015). Results indicate that deployment might affect different types of stressors, for example, financial stress or psychological stress, in diverse ways and also that these can be ameliorated by social support functions (Westhuis 1999; Dandeker et al. 2015; Green et al. 2013).

Similarly, the frequency of deployment has proven to influence stress within military families. For example, Van Winkle and Lipari (2013) used a large-scale survey and examined the relation between the number of deployments experienced by female spouses of active-duty military members and these spouses' perceived stress. They found that spouses who had not experienced a deployment reported the 
lowest stress levels. Stress levels increase after initial deployments and decrease after approximately two deployments, which may indicate an element of resiliency that builds up as spouses get used to a deployment lifestyle. Stress levels again increase after several deployments, which may signify limitations to this resiliency over time.

Similar to the results of the studies cited above, a secondary finding showed that higher levels of social support predicted lower levels of stress, above and beyond the number of deployments. This relationship between social support and stress helped explain the negative relationship between parental status and stress. That is, spouses with children may have lower stress levels due to the social network that accompanies parental status. De Angelis and coauthors' (De Angelis et al. 2018) chapter on military families focuses on the length of deployment and its effects and finds similar patterns.

Over the years, research on military families has also come to include a focus on the impact of deployment for less studied groups, such as Army National Guards, veterans, and reservists (Wheeler and Torres Stone 2010; Dandeker et al. 2010; Van Slyke and Armstrong 2019). In the USA, reservists are often used in these missions, as a way to lift the burden of active-duty members of the armed forces. The families of reservists are less integrated into military life and may also be less aware of the support systems put in place to help them cope with separation (Segal and Segal 2006). Studies on the reserve forces in Canada and the UK show that reservists are, in a way, in an even more extreme situation in that they not only have to balance demands of family and work but also expectations that the civilian employer may have (Dandeker et al. 2010; Anderson and Goldenberg 2019).

\section{Other Military Family Stressors}

Compared to operational deployments, other "stressors" of military life have received less attention in the literature. A recent survey study of spouses in the Canadian Armed Forces (cited in Dursun et al. 2019) shows that military families face a number of stressors connected to military work. The top three included the employment of the partner, healthcare issues, and relocation due to military service. Burrell et al. (2006) found relocation especially stressful, and it has been identified as a key stressor in other studies (Dursun and Sudom 2015; Dursun et al. 2019). It is perhaps not surprising given how a family move impacts many parts of the daily life for the family as a whole. Other studies have highlighted challenges related to marital reconciliation (Andres et al. 2015; Tomforde 2015).

Andres and Moelker (2010) explore factors influencing children's well-being with fathers' deployed in out-of-area operations. Focusing on Dutch service members and their partners before, during, and after a deployment to Bosnia or Afghanistan, they find that "the great majority of the children adapted quite well to the separation and reunion" (Andres and Moelker 2010: 418). Key in this respect seems to be the well-being of mothers as it increases "the chances that children will also be doing well in the course of parental absence" (Andres and Moelker 2010: 418). This contrasts sharply with Skomorovsky and Bullock's study (2017) focusing on 
Canada, which finds that deployment negatively impacted children's well-being, routines, and family dynamics contributing to their stress. "Active distraction and social support seeking served as the most effective protective factors against deployment stress" (Skomorovsky and Bullock 2017: 654). Just as the other studies on the mental well-being of military spouses, these studies show that the conditions under which each effect prevails (positive or negative) may vary depending on a wealth of factors, ranging from type of deployment to broader societal structure.

The effects of the stressors identified above on the well-being of military spouses and children and on the relationship between the service member and his/her family members are not only significant at the individual level (Thomas et al. 2019). How stressors, such as separation, are handled can also influence the motivation of the soldier, making it a concern for the military organization. Military families and especially spouses have proven to be a significant factor when it comes to soldiers' motivation to deploy and stay on in the organization. Research shows that reintegration after deployment and marital reconciliation influence the willingness of service members to participate in future deployments (Moelker and van der Kloet 2006). Pluut and Andres (2019) found that positive experiences on behalf of the military family during deployment also enhance service members overall attitudes toward the military organization as well as their willingness to go on additional missions. As expected, both the process of reintegration and marital reconciliation benefited from an open attitude between spouses and a willingness to share the experiences that each partner had during their time apart (Moelker and van der Kloet 2006).

Research on American deployments in Korea illustrate that family adjustment, in turn, depends on the ability to communicate during deployment and the military leaders' support for families and soldiers (Segal and Segal 2006). Moelker and Andres (2019) also point to the importance of communication during deployment and how technological solutions for communication may help bridge the distance (see also Andres et al. 2015; Skomorovsky and Bullock 2017).

Although communication channels can be of great importance to keep the relationship going despite the distance, it can also create expectations that at times are hard to meet, thereby contributing to increased stress levels on behalf of both service and family members (Ender 1995; Faulk et al. 2012). Moreover, today service members and their families have higher expectations and demands on functioning channels of communication than before (Moelker et al. 2015).

\section{New Families, New Challenges?}

Societal transformation is another important topic that has kept scholars of military families occupied, particularly pertaining to the type of recruitment system and gender and age composition of the force. This discussion has taken two forms: first, the implications of a more diverse force on new kinds of military families and, second, the impact of a new type of military families on the military. In the USA, the end of conscription has led to a more gender-diverse force. Available statistics 
illustrate how female officers, and their family lives, differ from male officers. For example, servicewomen are less likely to be married and have children (Wahl and Randall 1996). Those who do marry are far more likely to marry male service members or veterans compared to their male compatriots and to have been married more than once (Masson 2019:47). Civilian husbands, on the other hand, will likely have a harder time integrating with the military community given that the norm still is that the officer on active duty is a man and that his spouse is a wife (Bourgh 1995; Little and Hisnanick 2007). Just like civilian wives, civilian husbands also tend to earn less than their military counterparts, although the difference is not as great as for the wives (ibid, 2007; Ziff and Garland-Jackson 2019).

With the lifting of bans of women serving in ground combat role in many states, another set of authors have focused on the trajectories of female service members (Duncanson and Woodward 2016; King 2015). Focusing on the Israeli case, EranJona (2010: 19) studied "gender arrangements in families of male and female career military personnel as viewed by their civilian spouses." The study analyzed the differences in attitudes toward family life and examined the differences in workfamily practices among the Israeli Defense Forces' career servicemen and servicewomen. The findings indicate that the:

IDF's heavy demands on career personnel, regardless of gender lead to the construction of family and couple arrangements that deviate from the norm in civilian Israeli-Jewish families of similar characteristics. For the servicemen, this demand creates a "traditional" role division model that places the entire burden of family work on their wives; for the servicewomen the same demands create a relatively "egalitarian" role division model, by placing more of the burden of "family chores" on their husbands. (Eran-Jona 2010: 19)

More recent work has showed that such widespread unfairness still holds strong not only in terms of career trajectory but also in terms of retention. Despite efforts to improve women's military representation, mid-career female officers leave "at twice the rate of male peers" and "women's turnover is influenced by family life including marriage and parenthood" (King et al. 2019: 1). Thus, this study explored a single career point (mid-career) at different family intersections (married, unmarried, with and without children) to elucidate work and family factors associated with female officers' retention decisions. Focusing on Air Force survey data, the authors find that "after accounting for satisfaction, work factors were insignificant for all subgroups, but family factors (as hypothesized) were significantly associated with married women's career intentions. Results suggest that policies targeting family support/ satisfaction may improve retention" (King et al. 2019: 1).

The second big topic of discussion has been on changes in family dynamics and interrelationships. Moelker, Rones, and Andres suggest that the figuration of the military family in most cases still can be depicted as a triad made up of father, mother, and one or more children. Dyadic family figurations of course exist in single-parent households or in households without children (Moelker et al. 2019), but they are less frequent. The three participants in the triad are interdependent, and their changing power relations determine its dynamics. Social changes challenge the relationships within the triad, the consequence being that the command household, 
in which the man holds disproportional discretionary power, is giving way to the negotiation household. In such a household, tensions and shifting power balances between father, mother, and child(ren) are being negotiated. Often the three are "equal political agents in the family diplomatic system" (Moelker et al. 2019: 9). The command household is seen as a model for hegemonic masculinity, which corresponds to the idea of the military as an institution. This implies that a shift toward a negotiation household model also challenges the idea of hegemonic masculinity. Since the partners in the triad are more equal today, the work-family conflict has become more intense (Andres et al. 2015; Ziff and Garland-Jackson).

\section{Social Support}

Another important and related body of research focuses on military families in relation to social support (Bartone 2015; Moellker et al. 2015; Siebler 2015). This debate encompasses studies that have explored social support structures for military families in general and when service members were deployed abroad. The perhaps most important change in this regard has been the evolution of the military organization into a "normal organization" as opposed to when the families lived in compounds. Variations among states and military service branches seem key in this respect.

Originally, military family support organizations often were established as a result of political activism by family members - making military families a political force (Stanley et al. 1990). The strategy used was co-option, and grassroots influence became institutionalized in different ways - it could be military personnel who facilitated volunteers but also volunteers working independently from the armed forces. Although the demands on military wives have lessened over time, even nowadays, they are generally expected to conduct volunteer duties and participate in family support activities for the benefit of the military organization (Harrell 2001; Hosek et al. 2002). Despite the fact that many of them are active on the labor market, they need to accommodate the demands that the military organization put on their spouses, including drills, training, and deployments abroad. Lysak (2019: 59) discusses the important role of women in the creation of the military profession, referring to the unpaid and undervalued work they do as being part of a "militaryfamily industry." Harrell has also argued that women may get involved in volunteer work to maintain the status of their husbands and that there are both formal and informal expectations on them to do so (Harrell 2001). The commitment of military wives also tends to depend on the rank of their husbands, with wives of more senior commanders and NCOs generally more engaged in volunteering (Moelker and van der Kloet 2006). An interview study with wives of service members of the British Army also revealed that some women perceived the rank of their husbands, rather than their own merits, to be the determinant of their own status (Dandeker et al. 2015).

Co-option has become a more difficult strategy today as there are more groups outside the AF with demands on influence and also more diverse groups. Previous 
research in the Netherlands has shown, for example, that some people get excluded for example, spouses to those deployed in observer missions or missions only including the air force (cited in Moelker and van der Kloet 2006). As mentioned above, civilian husbands of female officers also tend to be less embedded in the military community.

When discussing the role of the family as providers of support to cope with stress, Moelker and van der Kloet (2006) note that there are important variances between social support networks. They aim to classify different types of social support networks that are available to the individual and put forward a taxonomy that captures differences between levels of "dependency" on one axis and classifies the support relations on an individualized-communitarian continuum on the other. The variations in both the demands and the character of social support were illustrated in an interview study on British military wives, conducted by Dandeker et al. (2015). It revealed that these women did not, as their firsthand choice, turn to the military for social support during the time their husbands were deployed. They rather relied on informal networks for social support.

\section{Concluding Remarks: Continuing to Develop the Debate on Military Families}

The frontier of the ongoing debate on military families is heading in three main directions. First, most studies focusing on military families identify the tensions arising from military personnel belonging to two greedy institutions at the same time, the family and the military (for a review see Moelker et al. 2019). More could be done to escape this frame and to mirror recent transformation in societies. King (2015) talks about "a quite radical transformation in social-military relations whereby the change is profound, complex and even paradoxical" (King 2015: 1). Wong and Gerras (2015) in their analysis of forward operating bases (FOB) suggest that the relations between individual service members and their partner and children have become more intense and that they have infiltrated the military professions in operations even in FOB. King $(2015: 1)$ asserts that a "domestic-military nexus is observable, reflecting a wider transformation of gender relations." Also, more recent patterns of deployment, such as the use of the military domestically, might shed light on some of it.

Second, research on military families has traditionally taken a multidisciplinary approach with contributions from psychology, sociology, history, anthropology, and more. Yet the field would also benefit from a political science perspective, especially as the character of the state, in regard to how traditional, nationalistic, secular, or globalist it is, will matter for what issues become interesting to look at and also what states are suitable for comparisons. On the point of comparison, the paucity of studies taking a comparative approach is somewhat surprising. While the literature acknowledges that the level of greediness varies over time and between armed forces, no research so far has systematically reflected on how the greediness of the family also depends on the characteristics of the state. Only very recently, Moelker et 
al. (2019) distinguish between three levels of analysis: the state (macro), the organization (meso), and the family level (micro). They suggest that by studying the military family, insights are gained as to how the military organization and the state change (2019: 10). Although it seems obvious that state-level changes will impact the military organization and the family/individual, it appears counterintuitive to use a bottom-up perspective to capture this. A rewarding starting point could indeed be the very character of the state or the level of trust in state institutions. Overall, to be useful on a broader scale, these aspects need to be considered. Since military families often are seen as crucial regarding their support functions, it will matter what logic underpins the welfare state at hand (see Kasearu and Olsson 2019 for an example). It seems plausible that in a welfare state based on the so-called male breadwinner logic and a traditional division of paid and unpaid household work between the husband and wife, the family will be less inclined to place other demands on the individual military serviceman than in a social welfare state based on the working adult logic (Esping-Andersen 1990).

Relatedly, it might be worth reflecting on the context-specific relationship between the state and the individual. To illustrate, both Sweden and the USA score high in terms of individualism. Yet the kind of expected relationship between the individual and the state could not be more different. Despite the fact that Sweden is a state that, just like the USA, is considered highly individualistic, trust in institutions is high, levels of corruption are low, and the state is considered a precondition for individual freedom rather than a greedy institution (Rothstein 1998). This implies in the case of Sweden, a "big" state that provides services, generous parental leave, and better child care, thereby making the military and the family relatively less greedy. By contrast, the USA supports a state that is small in size and values individual freedom (including state intrusion), which would result in a relatively more greedy family.

Furthermore, another problem with using the family as a unit of analysis is that it is not always recognized as important by the affected. In Scandinavia, the military is not seen as a distinctive entity with ambitions of governance, and the gap between civil society and the military is not perceived as troublesome (Ledberg 2019). In Sweden, families that in international research would be identified as military families do not identify themselves as such (Olsson and Olsson 2019). Instead, they are seen as similar to any other working family and are part of the same welfare regime (Kasearu and Olsson 2019). Although the literature sometimes takes into account that families are not always made up of father, mother, and child, many studies continue to assume a traditional family structure. Eran-Jona and Aviram's study on new families in the Israeli Defense Forces and Skomorovsky, Bullock, and Wan's study on single parents in the Canadian AF are important exception to this rule (Eran-Jona and Aviram 2019; Skomorovsky et al. 2019).

Third, the debate on military families would benefit from a better connection to other studies in military sociology relating to the transformation of the military profession. (This chapter has an author and I believe the author's name should be used. See comments below.) (For an overview of what military sociology encompasses, see chapter on " Military Sociology.") Other key themes in military 
sociology may certainly influence the discourse on military families. When we think about cohesion dynamics, King has variously written about how professionalism could be the source of new forms of cohesion, based on repetition and drills (A. King 2007). Following this logic, anybody with the right competence should be able to participate in small groups, and that should of course also open up to women (see also chapter on “ $\triangleright$ Military Women”). This would imply longer deployment also for women, higher levels of retention, and potential consequences of challenges of military families. Notwithstanding the transformation of the military, military families remain a highly important locus where operational experiences are made sense of. Gustavsen in her work explores the role of military families for meaning-making exercises (Gustavsen 2016). Similarly, Sarah Kayss (2018) writes on how memory influences recruitment strategies in the officer corps in the UK and Germany. This work highlights the importance of belonging to a military family. Relatedly, the literature on military families extends to the transition to the civilian sector and veteran status as discussed in the chapter on " $\triangleright$ Veterans and Reservists: Views from Within and Without." There is indeed a literature on veteran families that mirrors many of the issues found in the military family literature generally. In summary, the field of military families arguably needs to engage in broader conversations with other related debates in military sociology, such as the one on veterans, expeditionary operations, cohesion, and the gendered nature of the military institution as seen in the persistency of sexual assault and harassment. Across all these debates, the negotiations of roles within the individual seem of great importance. (We gratefully acknowledge Vince Connelly for raising this point at the IUS conference 2019.)

Fourth and final, it is telling that the majority of studies are still single-case studies, dominated by a US focus, and that most of them are descriptive. More comparative, theory development work is needed to continue the cumulative research progress of this importance debate within military sociology.

\section{Cross-References}

TBA

\section{References}

Anderson, J. E., \& Goldenberg, I. (2019). Balancing act: The demands of family, military service, and civilian employment for reservists. In R. Moelker, M. Andres, \& N. Rones (Eds.), The politics of military families: State, work organizations, and the rise of the negotiation household. Abingdon: Routledge.

Andres, M. D., \& Moelker, R. (2010). There and back again: How parental experiences affect children's adjustments in the course of military deployments. Armed Forces \& Society, 37(3), 418-447. https://doi.org/10.1177/0095327X10390461.

Andres, M. D., De Angelis, K., \& McCone, D. (2015). Reintegration, reconciliation, and relationship quality. In M. René, M. Andres, G. Bowen, \& P. Manigart (Eds.), Military families and war in the 21st century: Comparative perspectives. Abingdon: Routledge. 
Baker, A. P. (2004). American soldiers overseas: The global military presence. Westport: Praeger. Bartone, J. (2015). Missions alike and unlike: Military family support in war and peace. In R. Moelker, M. Andres, G. Bowen, \& P. Manigart (Eds.), Military families and war in the 21st century. Comparative perspectives (pp. 193-209). Oxon and New York: Routledge.

Bartone, P. T., Adler, A. B., \& Vaitkus, M. A. (1998). Dimensions of psychological stress in peacekeeping operations. Military Medicine, 163(9), 587-593.

Bourgh, C. (1995). Male tokens in a masculine environment: Men with military mates. In Paper presented at the 1995 annual meeting of the American sociological association. Available at https://chrisbourg.files.wordpress.com/2012/11/male-tokens.pdf. Accessed 13 Dec 2019.

Buckman, J. E., Sundin, J., Greene, T., Fear, N. T., Dandeker, C., Greenberg, N., \& Wessely, S. (2011). The impact of deployment length on the health and well-being of military personnel: A systematic review of the literature. Occupational and Environmental Medicine, 68, 69-67.

Burrell, L. M., Adams, G. A., Durand, D. B., \& Castro, C. A. (2006). The impact of military lifestyle demands on well-being, Army, and family outcomes. Armed Forces \& Society, 33(1), 43-58. https://doi.org/10.1177/0002764206288804.

Button, E. D., \& Diallo, A. B. (2020). Voting behavior of active duty military spouses: Trends in interest and participation. Armed Forces \& Society. https://doi.org/10.1177/ $0095327 X 19901295$.

Dandeker, C., Eversden, C., Birtles, C. \& Wessely, S. (2015). The British military family: The experiences of British Army wives before, during, and after deployment, their satisfaction with military life, and their use of support networks. In: Moelker R., Andres, M., Bowen, G., \& Manigart, $\mathrm{P}$ (eds.) Military families and War in the 21st century: Comparative perspectives. Oxon \& New York: Routledge, 107-128.

Dandeker, C., Eversden-French, C., Greenberg, N., Hatch, S., Riley, P., van Staden, L., \& Wessely, S. (2010). Laying down their rifles: The changing influences on the retention of volunteer British Army reservists returning from Iraq, 2003-2006. Armed Forces \& Society, 36(2), 264 289.

De Angelis, K., \& Segal, M. W. (2015). Transitions in the military and the family as greedy institutions: Original concepts and current applicability. In M. René, M. Andres, G. Bowen, \& P. Manigart (Eds.), Military families and war in the 21st century: Comparative perspectives. Abingdon: Routledge.

De Angelis, K., Smith, D. G., \& Segal, M. W. (2018). Military families: A comparative perspective. In G. Caforio \& M. Nuciari (Eds.), Handbook of the sociology of the military (pp. 341-357). Springer International Publishing. https://doi.org/10.1007/978-3-319-71602-2_17.

Duncanson, C., \& Woodward, R. (2016). Regendering the military: Theorizing women's military participation. Security Dialogue, 47(1), 3-21. https://doi.org/10.1177/0967010615614137.

Dursun, S., \& Sudom, K. (2015). The well-being of military families: Coping with the stressors of military life among spouses of Canadian Armed Forces members. In M. René, M. Andres, G. Bowen, \& P. Manigart (Eds.), Military families and war in the 21st century: Comparative perspectives. Abingdon: Routledge.

Dursun, S., Wang, Z., \& Pullman, L. (2019). Military lifestyle stressors and social support in the well-being of military families. In R. Moelker, M. Andres, \& N. Rones (Eds.), The politics of military families: State, work organizations, and the rise of the negotiation household. Abingdon: Routledge.

Ender, M. G. (1995). G.I. phone home: The use of telecommunications by the soldiers of operation just cause. Armed Forces \& Society, 21(3), 435-453.

Eran-Jona, M. (2010). Married to the military: Military-family relations in the Israel defense forces. Armed Forces \& Society, 37(1), 19-41. https://doi.org/10.1177/0095327X10379729.

Esping-Andersen, G. (1990). The three worlds of welfare capitalism. Princeton: Princeton University Press.

Everson, B. R., Darling, C., Herzog, J., Figley, C. R., \& King, D. (2017). Quality of life among U.S. Army spouses during the Iraq war. Journal of Family Social Work. https://doi.org/10.1080/ 10522158.2017.127957. 
Faulk, K. E., Gloria, C. T., Cance, J. D., \& Steinhardt, M. A. (2012). Depressive symptoms among US military spouses during deployment: The protective effect of positive emotions. Armed Forces \& Society, 38(3), 373-390. (Just a strong study that should be included).

Green, S., Nurius, P. S., \& Lester, P. (2013). Spouse psychological well-being: A keystone to military family health. Journal of Human Behavior in the Social Environment, 23(6), 753-768. https://doi.org/10.1080/10911359.2013.795068.

Gribble, R., Goodwin, L., Oram, S., \& Fear, N. T. (2019). "Happy wife, happy soldier": How the relationship between military spouses and the military institutions influences spouse well-being. In R. Moelker, M. Andres, \& N. Rones (Eds.), The politics of military families : State, work organizations, and the rise of the negotiation household. Abingdon: Routledge.

Gustavsen, E. (2016). The construction of meaning among Norwegian Afghanistan veterans. International Sociology, 31(1), 21-36. https://doi.org/10.1177/0268580915613191.

Harrell, M. C. (2001). Army officers' spouses: Have the white gloves been mothballed? Armed Forces \& Society, 28(1), 55-75.

Heinecken, L., \& Wilén, N. (2019). No place like home? Postdeployment reintegration challenges facing South African peacekeepers. Armed Forces \& Society. https://doi.org/10.1177/ $0095327 X 19894719$.

Hosek, J., Asch, J. B., Fair, C. C., Martin, C., \& Mattock, M. (2002). Married to the military: The employment and earnings of military wives compared with those of civilian wives. Santa Monica: Rand.

Kasearu, K., \& Olsson, A. M. (2019). A systemic perspective on children's well-being in military families in different countries. Journal of Military, Veteran and Family health, 5(S2), 79-97. Published Online: November 11, 2019.

Kayss, S. K. (2018). Identity, motivation and memory: The role of history in the British and German forces. London: Routledge.

King, A. (2007). The existence of group cohesion in the armed forces: A response to guy Siebold. Armed Forces \& Society, 33(4), 638-645. https://doi.org/10.1177/0095327X07301445.

King, A. (2015). Frontline combat and cohesion in twenty-first century. Oxford: Oxford University Press.

King, A. (2019). Command. In Command: The twenty-first-century general (pp. i-ii). Cambridge: Cambridge University Press.

King, E. L., DiNitto, D., Salas-Wright, C., \& Snowden, D. (2019). Retaining women air force officers: Work, family, career satisfaction, and intentions. Armed Forces \& Society, XX(X), 119. https://doi.org/10.1177/0095327X19845024.

Ledberg, S. (2019). Officeren, staten och samhället: ett professionsperspektiv. Lund: Nordic Academic Press.

Little, R. D., \& Hisnanick, J. H. (2007). The earnings of tied-migrant military husbands. Armed Forces \& Society, 33(4), 547-570.

Lysak, E. (2019). The military-family industry: The role of the family in the construction and development of the military profession. In R. Moelker, M. Andres, \& N. Rones (Eds.), The politics of military families : State, work organizations, and the rise of the negotiation household. Abingdon: Routledge.

Mansfield, A. J., Kaufman, J. S., Marshall, S. W., Gaynes, B. N., Morrissey, J. P., \& Engel, C. C. (2010). Deployment and the use of mental health services among U.S. Army wives. New England Journal of Medicine, 362, 101-109.

Masson, L. (2019). Tensions and negotiations surrounding the inclusion of female officers in the Brazilian Air Force. In R. Moelker, M. Andres, \& N. Rones (Eds.), The politics of military families: State, work organizations, and the rise of the negotiation household. Abingdon: Routledge.

Meadows, S. O., Griffin, B. A., Karney, B. R., \& Pollak, J. (2016). Employment gaps between military spouses and matched civilians. Armed Forces \& Society, 42(3), 542-561.

Moelker, R. \& Andres, M. (2019). Epilogue: dating from a distance - love and separation in a networked society. In Moelker, R, M. Andres, \& N. Rones, N. (Eds.), The politics of military 
families: state, work organizations, and the rise of the negotiation household Abingdon: Routledge.

Moelker, R., \& van der Kloet, I. (2006). Military families and the armed forces. In G. Caforio (Ed.), Handbook of the sociology of the military (pp. 201-223). Boston: Springer US. https://doi.org/ 10.1007/0-387-34576-0_12.

Moelker, R., Andres, M., \& Rones, N. (2019). Introduction. In R. Moelker, M. Andres, \& N. Rones (Eds.), The politics of military families: State, work organizations, and the rise of the negotiation household. Abingdon: Routledge.

Moellker, R., Andres, M., Bowen, G., \& Manigart, P. (2015). Introduction. In R. Moelker, M. Andres, G. Bowen, \& P. Manigart (Eds.), Military families and war in the 21st century. Comparative perspectives. Abingdon/New York: Routledge.

Olsson, A. E., \& Olsson, S.-E. (2019). Swedish families' responses to military deployment. In R. Moelker, M. Andres, \& N. Rones (Eds.), The politics of military families: State, work organizations, and the rise of the negotiation household. Abingdon: Routledge.

Pluut, H., \& Andres, M. (2019). The influence of work-family experiences during military deployment on organizational outcomes. In R. Moelker, M. Andres, \& N. Rones (Eds.), The politics of military families: State, work organizations, and the rise of the negotiation household. Abingdon: Routledge.

Rothstein, B. (1998). Just institutions matter: The moral and political logic of the universal welfare state. Cambridge: Cambridge University Press.

Segal, M. W. (1986). The military and the family as greedy institutions. Armed Forces \& Society, 13 (1), 9-38. https://doi.org/10.1177/0095327X8601300101.

Segal, M. W. (1989). The nature of work and family linkages: A theoretical perspective. In G. L. Bowen \& D. K. Orthner (Eds.), The organization family: Work and family linkages in the U.S. military. New York: Praeger.

Segal, M. W., \& Jesse, J. H. (1993). What we know about Army families. Alexandria: U.S. Army Research Institute for the Behavioral and Social Sciences.

Segal, D. R., \& Segal, M. W. (1993). Peacekeepers and their wives: American participation in the multinational force and observers. Westport: Praeger.

Segal, M. W., \& Segal, D. R. (2006). Implication for military families of change in the armed forces of the United States. In G. Caforio (Ed.), Handbook of the sociology of the military (pp. 225233). Boston: Springer.

Segal, M. W., Xiaolin, L., \& Segal, D. R. (1992). The role of women in the Chinese People's liberation Army. Minerva, 10, 48-55.

Siebler, P. (2015). 'Down under': Support for military families from an Australian perspective. In R. Moelker, M. Andres, G. Bowen, \& P. Manigart (Eds.), Military families and war in the 21st century. Comparative perspectives (pp. 287-301). New York: Routledge.

Skomorovsky, A., \& Bullock, A. (2017). The impact of deployment on children from Canadian military families. Armed Forces \& Society, 43(4), 654-673. https://doi.org/10.1177/ $0095327 X 16670691$.

Skomorovsky, A., Bullock, A., \& Wan, C. (2019). Single parents in the Canadian Armed Forces: The impact of military life on psychological distress. In R. Moelker, M. Andres, \& N. Rones (Eds.), The politics of military families: State, work organizations, and the rise of the negotiation household. Abingdon: Routledge.

Stanley, J., Segal, M. W., \& Laughton, J. (1990). Grass roots family action and military policy respones. Marriage and Family Review, 15(3/4), 220-221.

Thomas, J. L., Adrian, A. L., Wood, M. D., Crouch, C. L., Lee, J. D., \& Adler, A. B. (2019). Mental health and stress among Army civilians, spouses, and soldiers in a closing military community. Armed Forces \& Society, 45(4), 612-636.

Tomforde, M. (2015). The emotional cycle of deployment. In M. René, M. Andres, G. Bowen, \& P. Manigart (Eds.), Military families and war in the 21st century: Comparative perspectives. Abingdon: Routledge. 
Van Slyke, R. D., \& Armstrong, N. J. (2019). Communities serve: A systematic review of need assessments on U.S. Veteran and military-connected populations. Armed Forces \& Society. https://doi.org/10.1177/0095327X19845030.

Van Winkle, E. P., \& Lipari, R. N. (2013). The impact of multiple deployments and social support on stress levels of women married to active duty servicemen. Armed Forces \& Society, 41(3), 395-412. https://doi.org/10.1177/0095327X13500651.

Wahl, C., \& Randall, V. F. (1996). Military women as wives and mothers. Women's Health Issues, 6 (6), 315-319.

Westhuis, D. J. (1999). Working with military families during deployment. In J. G. Daley (Ed.), Social work practice in the military. New York: Haworth Press.

Wheeler, A. R., \& Torres Stone, R. A. (2010). Exploring stress and coping strategies among national guard spouses during times of deployment: A research note. Armed Forces \& Society, $36(3), 545-557$.

Winslow, D. (1997). The Canadian airborne regiment in Somalia: A socio-cultural inquiry. Minister of Public Works and Government Services Canada.

Wong, L., \& Gerras, S. (2015). Of FOBS and families. In A. King (Ed.), Frontline. Combat and cohesion in the XXI century. Cambridge: Cambridge University Press.

Ziff, E., \& Garland-Jackson, F. (2019). "I'm not your 'typical' military wife": The construction of gender and agency through stereotypes. Armed Forces \& Society. First view.

Open Access This chapter is licensed under the terms of the Creative Commons Attribution 4.0 International License (http://creativecommons.org/licenses/by/4.0/), which permits use, sharing, adaptation, distribution and reproduction in any medium or format, as long as you give appropriate credit to the original author(s) and the source, provide a link to the Creative Commons license and indicate if changes were made.

The images or other third party material in this chapter are included in the chapter's Creative Commons license, unless indicated otherwise in a credit line to the material. If material is not included in the chapter's Creative Commons license and your intended use is not permitted by statutory regulation or exceeds the permitted use, you will need to obtain permission directly from the copyright holder.

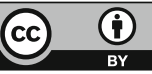

